DOI 10.37882/2223-2982.2021.09-2.25

\title{
ПОЛИТИКА ГОСУДАРСТВА ПО ОТНОШЕНИЮ К СТАРООБРЯДЦАМ В ПЕРИОД ПРАВЛЕНИЯ АЛЕКСАНДРА І И НИКОЛАЯ ІІ
}

\section{STATE POLICY TOWARDS THE OLD BELIEVERS DURING THE REIGN OF ALEXANDER I AND NICHOLAS II \\ O. Yagudina E. Tomina}

Summary: In modern Russian society, the issues of interaction of religious cultures, tolerance and the rule of law are touched upon. The article studies and analyzes in detail the state policy towards the Old Believers in the XIX century, its results and consequences. In the course of the study, it was determined that after M.M. Speransky codified the legislative material accumulated over a couple of centuries and formalized it in the form of a Complete collection of laws and a Code of Laws of the Russian Empire, six religious torts are mentioned in the section on crimes and on faith. During the reign of Nicholas I, large monasteries were destroyed, and that part of the schismatics who refused to join the same faith will begin searching for their own Belokrinitsky hierarchy.

Keywords: politics, church, Cossacks, Orthodoxy, schismatics, Old Believers, legislation.
$\mathrm{O}$ дним из значительных событий русской истории является церковный раскол в XVII веке. Причинами его возникновения стали не только догматические разногласия, как это было принято считать в исторической литературе XVIII-XIX веков. Раскол, носивший первоначально протестный характер, был обусловлен ухудшением социально-экономического положения низших слоев русского общества. Крестьяне, казаки, торговые и посадские люди, оказавшиеся под гнетом государства и землевладельцев, составили социальную базу старообрядчества.

Приверженность старой вере, на протяжении нескольких веков, расценивалось властями, как преступление против государства, а сами раскольники считались людьми, идущими «в разлад с общественным устройством России» [4, с. 453]. Главные обвинения, выдвигаемые против староверов, по мнению известного русского правоведа А.Ф. Кони, «не верят в церковную власть, отрицают государственный авторитет и не признают супружеских союзов» [4, с. 455]. При этом в XIX столетии сохранялось ошибочное представление о старообрядчестве как о сектантском движении. Причисление староверов к «изуверным учениям» оказывало суще-

\author{
Ягудина Оксана Валентиновна \\ К.и.н., дочент, Оренбургский государственный \\ университет \\ yagudina_ov@mail.ru \\ Томина Елена Федоровна \\ К.п.н., дочент, Оренбургский государственный \\ университет \\ teador17@mail.ru
}

Аннотация: В современном российском обществе затрагиваются вопросы взаимодействия религиозных культур, толерантности и правового государства. В статье подробно изучается и анализируется государственная политика по отношению к староверам в XIX столетии, ее итоги и последствия. B процессе исследования определено, что после проведения кодификации M.M. Сперанским накопившегося за пару веков законодательного материала и оформления его в виде Полного собрания законов и Свода законов Российской империи, в разделе о преступлениях и о вере упоминается шесть религиозных деликтов. В период правления Николая I уничтожались крупные скиты, и та часть раскольников, которая отказалась присоединиться к единоверию, начнет поиски собственной Белокриницкой иерархии.

Ключевые слова: политика, церковь, казачество, православие, раскольники, старообрядчество, законодательство.

ственное влияние на выбор проводимых государством мероприятий для борьбы с расколом. Отсутствовало четкое представление о толках и согласиях, имевших место в старообрядчестве. Часто один и тот же толк упоминался «по два раза под разными именами ..., тогда как это один толк, который лишь иначе именуется в разных местностях» [4, с. 451].

Долгое время преследование религиозных преступлений являлось прерогативой церкви. Светская же власть стала принимать активное участие в этих вопросах только во второй половине XVII века. В разные исторические периоды раскольников могли судить как церковным судом, так и светским. Значительные изменения в жизни старообрядцев произошли в рассматриваемый нами период.

Для Российской империи XIX век стал временем серьезных изменений в жизни государства и общества. Перемены коснулись и государственно-конфессиональной политики по отношению к старообрядцам. Позиция властей зависела не только от идеологии старообрядческого толка или согласия, но и к какому сословию относились раскольники. 
На особом счету были казаки-старообрядцы, так как они составляли военное сословие и были опорой царской власти на государственных рубежах. Среди казачьих войск Российской империи наибольшее количество староверов проживало на территориях: Уральском - 63346 (50\%), Тёрском - 28420 (15,6\%), Донском 113640 (10,1\%), и Оренбургском - 18341 (4,6\%) [14, с. 54].

Начало изучаемого периода ознаменовано появлением единоверческой церкви, где разрешалось вести службы по старопечатным богослужебным книгам. Практика единоверия была окончательно закреплена в «16 пунктах» митрополита Платона при императоре Павле I в 1800 году. Для многих старообрядцев это стало решением вопроса нехватки священнослужителей, а для государства - надежда на то, что единоверие станет промежуточным этапом при переходе раскольников в новообрядческую церковь. При достижении данной цели церковь единоверия, как институт, становилась ненужной и подвергалась уничтожению. Но раскольники, если и принимали единоверие, то только из-за стремления получить собственную иерархию. Дальнейшего перехода в официальное православие, чаще всего не происходило.

Одной из мер противодействия расколу стал указ от 1801 года, по которому православные, уклоняющиеся от христианских таинств исповеди и причастия, освобождались от денежного штрафа. Вместо этого назначалось церковное покаяние. Введение данного положения объяснялось тем, что с раскольников уже давно сняты денежные штрафы, а это служит для некоторых православных слабых в вере к удалению от церкви. Выгоднее было признать себя раскольником, чем нести ответственность за нарушение[7, Т. XXVI. №19743. с. 521-523].

Преемник Павла I, Александр I (1801-1825), начал свое правление с либеральных преобразований, которые были направлены на все сферы общественной жизни, в том числе и на религиозную. Несмотря на то, что они были достаточно сдержаны по отношению к старообрядчеству, исследователь Н.И. Субботин пришел к выводу, что такая политика способствовала укреплению и процветанию раскола[12, с. 119]. В большей степени ослабление контроля за расколом в это время коснулось старообрядцев-поповцев, как более лояльных к власти.

Изменения в общественной жизни требовали и пересмотра подхода к мерам наказания за религиозные преступления. Так, к примеру, в 1817 году был издан указ «О нервании ноздрей у преступников», посчитав это истязание излишним и бесчеловечным. Изначально предполагалось, что данная мера заменит смертную казнь и оставит неизгладимый знак преступления [7, T. XXXIV. №27197. С. 949]. На особом контроле с 1820 года у полиции оставались представители федосеевского согласия, в общинах которых были обнаружены факты «разврата и детоубийства» [2, с. 423-428]. Для них так же устанавливался запрет избрания их представителей на общественные должности.

Еще одним послаблением для старообрядцев в царствование Александра I стало разрешение в 1822 году содержать часовни и держать беглых попов, за которыми нет уголовного преследования. С этих пор наблюдается трансформация раскола «из религиозной секты в обширную промышленную корпорацию», которая проникла почти во все отдаленные регионы Российской империи[6, с. 18].

С приходом к власти Николая I (1825-1855) прервалась преемственность политики веротерпимости. Его царствование совпало с периодом жестких гонений, которое отразилось на всем старообрядческом обществе. По мнению императора, раскол «беспокоит Церковь, отводя многих от соединения с нею...», а старообрядцы «властей светских и духовных как внутренне сами не любят, так и других своим примером, а при том и глухими разговорами на то же приводят или привести всегда хотят» $[10$, с. 145].

Вопросами раскола при Николае I стало ведать III Отделение его императорского величества канцелярия. Первыми мероприятиями по отношению к раскольникам стали лишение их права быть избранными на общественные должности и запрет на запись в купеческие гильдии. Старообрядческие общины признавались незаконными [2, с. 423-428].

При этом при Николае I была проведена кодификация всего накопившегося за пару веков законодательного материала, который был обобщен усилиями М.М. Сперанского и оформлен в виде Полного собрания законов и Свода законов Российской империи. В разделе о преступлениях о вере упоминается шесть религиозных деликтов: богохуление и порицание веры, вероотступничество и отвлечение от веры, ересь и раскол, подложное проявление чудес, нарушение благочиния в церквях, святотатство[16, с. 428]. Практически все перечисленные выше преступления карались лишением всех прав состояния и каторжной ссылкой до 15 лет, заключением в смирительном доме сроком до 3 лет. Интересен тот факт, что совершенные религиозные преступления в пьяном состоянии, карались более мягкими мерами. К примеру, за оскорбление в пьяном состоянии священника в церкви приговаривали до 3 месяцев тюремного заключения. Если же совершивший преступление был трезв, то срок мог составить около 6 месяцев тюрьмы.

Исследователи Н.М. Чернавский и П.Н. Столпянский в своих работах отмечали, что исполнители царских указов, превышая свои полномочия, значительно уве- 
личивали наказание. Тюремные остроги Оренбургской губернии были переполнены раскольниками, что значительно усугубляло состояние раскола в губернии[15, с. 998]. Для полиции и исправников старообрядцы выступали, как «средство поправить свой скудный бюджет» [11, с. 102].

Остро стоял вопрос и о беглых старообрядческих попах, которые совершая поездки по самым отдаленным уголкам Российской империи, способствовали укреплению и распространению раскола. Беглые священники находили на территории казачьих войск приют и поддержку в виде материальной помощи, так как здесь всегда ощущалась нехватка своих священнослужителей. Тогда в 1832 году было издано высочайшее повеление, где указывался запрет укрывать вновь прибывших беглых попов и «только прежних оставить в покое». Повеление распространялось на всю территорию государства, и казачьи территории не стали исключением[15, с. 426]. Введение запрета совпало с разгромом Иргизских монастырей, которые для многих раскольников являлись иерархическим центром. Теперь они переводились в статус единоверческих. Итогом стала радикализация старообрядчества Иргиза. Многие из них примкнули к беспоповцам или к другим сектам[13, с. 193]. Другим важным следствием разгрома Иргиза стал поиск священства, и затем появление Белокриницкой (австрийской) иерархии, ставшей основой для одной из крупнейших старообрядческих общин во второй половине XIX века. «Австрияки» стали главными конкурентами для официального православия, так как имели собственную иерархию и были более привлекательны, чем, к примеру, церковь единоверия, где раскольники ощущали двойственность своего положения.

Через несколько лет в 1839 году происходит ужесточение наказания за укрывательство среди казачества беглых священников. Теперь, если на войсковой территории будет пойман такой поп, то за каждого попа назначался штраф в 600 рублей. Ровно половину было обязано выплатить станичное правление[5, с. 230-231], которое несло ответственность за недосмотр.

В 1836 году еще одним запретом стало обращение крестьянских изб в старообрядческие молельни, а так же устраивать в них престолы. Это не относилось к молебным домам, созданным до данного постановления на основании действующих законов[8, Т. ХІ. Ч. 1. №9107. C. 446-447].

В сентябре этого же года Комитет министров издал положение, по которому старообрядцам, принявшим православие, даровалось прощение единожды. Повторно «совратившихся» в раскол отправляли на проживание в Закавказские провинции. Фактически данное положение подтверждало статьи 192 и 195 Свода Законов
Уголовных[8, Т. ХІ. Ч. 2. №9494. С. 1]. Последующим указом разрешалось раскаявшимся и обратившимся в православие старообрядцам остаться в Тифлисе или других регионах Закавказья, если на то есть согласие местных обществ[8, Т. ХІ. Ч. 2. №9538. С. 34-35].

В 1838 и 1839 годах были узаконены основные положения «О порядке предания земле тех раскольников, умерших в селениях ведомства государственных имуществ». Закон касался тех старообрядцев, которые не приемлют священства. Теперь их тела можно было предать земле только после освидетельствования местной полицией. В обязанности полиции вменялось наблюдение за тем, чтобы погребение совершалось не ранее установленного срока. Через год вышло разъяснение. Освидетельствование тела полицией состоит только в простом осмотре, чтобы выяснить была ли смерть насильственной. Если возникали подозрения в убийстве или был соответствующий донос, то инициировалось судебно-медицинское исследование [1, оп. 5. д. 10910, л. 1].

Согласно указу от 1845 года последователи староверия не допускались до работы в иконописных цехах. Данная мера обосновывалась стремлением предупредить «неприличные изображения на иконах». Тех, кто скрывал свою принадлежность к расколу или был совращен в раскол в то время, когда состоял в цехе, исключался из него. Сокрытие принадлежности к старой вере воспринималось как ложное показание перед судом, такие раскольники подвергались уголовному преследованию [8, Т. XX. Ч. 1. №18590. С. 78].

Со временем идеологически неоднородное старообрядческое движение окончательно раскалывается на два крупных течения - беспоповцы и поповцы. В XIX веке наибольшую популярность приобретает поповское течение, которое имело распространение в местах со смешанным по сословиям населением и с развитым денежным хозяйством [3, с. 150]. Возможно, это объяснялось тем, что поповцы готовы были пойти на компромисс с властями для улучшения условий своей торговой и общественно-политической деятельности. Предоставляемые поповцам льготы делали более привлекательным присоединение к их общинам. Беспоповцы же, среди которых было больше всего выходцев из крестьянского сословия, имели значительные ограничения в гражданских и экономических правах. К середине XIX века правительство разработало свою классификацию раскольников, которая определялась особенностями вероучения:

1. Секты вреднейшие, куда беспоповцы, отвергавшие молитву за царя и брак, входили вместе с иудействующими, молоканами, духоборами, хлыстами, скопцами.

2. Вредные. К этому разряду относили беспоповцев, допускающих брак и молитву за царя. 
3. Менее вредные - поповцы. Раскольники данного разряда преследовались только в случае публичного оказательства раскола.

С 1845 года, согласно указу Святейшего Синода, православным священникам не разрешалось вмешиваться в раскольничьи требы [1, оп. 4. д. 8193, л. 3].

Уральский атаман Перовский В.А. впоследствии отмечал, что данная мера предоставила преимущества для старообрядцев. На практике священники лишились возможности к обличению раскола. Духовные увещания могли проводиться только в благоприятные к собеседованию случаи. Запрещалось входить в дома раскольников, которые были приспособлены для проведения таинств и молитв, так как это могло повлечь за собой «ропот и жалобы на священников» [15, с. 620].

В августе 1845 года было издано Уложение «о наказаниях уголовных и исправительных». Статьи 197, 206215 содержали положения о санкциях, применяемых к религиозным преступникам. Наказание виновного в открытой проповеди раскола состояло в заключении в смирительный дом на срок до двух лет и потере особенных сословных прав:

- для дворян - запрет на государственную или общественную службу, участие в выборах на какиелибо должности;

- для священников - пожизненная потеря духовного сана;

- для почетных граждан и купцов - запрет участвовать в выборах и избираться на городские должности.

Дважды, совершенное преступление каралось заключением в крепость от 4 до 6 лет, трижды - ссылкой в Томскую и Тобольскую губернии. Если распространение старообрядчества сопровождалось применением насилия, то помимо перечисленных выше видов наказания ссылали на каторжные работы в рудники на 12-15 лет и вводился запрет иметь крепостных православного вероисповедания, а также управлять имениями с православным населением [8, Т. ХХ. Ч. 1. №19283. С. 631-632]. Возведение старообрядческих скитов, молебных домов влекло за собой заключение в тюрьму на срок от 1 до 2 лет. Все строения подвергались сносу, а материалы строения продавались в пользу Приказа общественного призрения [8, Т. XX. Ч. 1. №19283. С. 634-635].

Исследователь А.С. Пругавин отмечал, что отбывание наказания иногда затягивалось на долгие годы. В пример он приводит список арестантов Соловецкой тюрьмы, составленный по требованию Синода в 1855 году. Здесь были указаны узники, которые отбывали срок уже более 30-40 лет, за приверженность старой вере и произнесение богохульных слов на официальную церковь. Особое внимание А.С. Пругавина привлекала фигура крестьянина Семена Шубина, сидевшего уже 43 года. На тот момент ему исполнилось 88 лет. В заключении было отмечено, что данный арестант оставлен в монастырской тюрьме на неопределенный срок, так как «безнадежен в раскаянии» [9, с. 58-59]. В данном отчете автор сделал пометку, что арестанты Соловецкой тюрьмы лишены всякой медицинской помощи из-за отсутствия лекарств и медиков. В гражданские больницы отправлялись только те, кто впадал в сумасшествие [9, с. 66].

Браки бывших раскольников указом Синода от 1853 года предписывалось венчать только после их «искреннего» присоединения к официальному православию и оставлению раскольнических заблуждений. Они обязывались пребывать неуклонно в официальном православии или в единоверческой церкви [15, с. 688].

Таким образом, давая оценку государственной политике в вопросах борьбы с расколом, необходимо отметить, что первая половина XIX века, была сложным и противоречивым периодом в истории старообрядчества. Если при Александре I были сделаны осторожные шаги к смягчению положения раскольников в империи, то при Николае I все либеральные преобразования в религиозной сфере были свернуты. Николаевское время стало самым мрачным и грозным в истории старообрядчества. Именно в эти годы был нанесен удар по раскольническому священству, так как уничтожение крупных скитов привело к его оскудению. Та часть раскольников, которая отказалась присоединиться к единоверию, начнет поиски собственной иерархии, итогом которых станет появление Белокриницкой иерархии.

\section{ЛИТЕРАТУРА}

1. Государственный архив Оренбургской области (ГАОО). Ф. 173. Оп. 4. Д. 8193; Д. 8448; Оп. 5. Д. 10910.

2. Знаменский П.В. История русской церкви. Париж: Центр русских исследований в Медоне; М.: Крутицкое Патриаршее подворье, 2000.

3. История современной России / Под ред. В.А. Поссе. Ч. 1. СПб.: Жизнь для всех, 1912.

4. Кони А.Ф. На жизненном пути. Т. 2. Из воспоминаний. Публичные чтения. В верхней палате. СПб.: Тип. Спб. т-ва печ. и изд. дела «Труд», 1912.

5. Материалы по историко-статистическому описанию. Хронологический перечень. Вып. Х. Оренбург: Типо-литография Б. Бреслина, 1910.

6. Москаленко А.Т. Идеология и деятельность христианских сект. Новосибирск: Наука. Сиб. отделение, 1978.

7. Полное собрание законов Российской империи. Первое собрание (1649-1825). T. XXVI. №19743; T. XXXIV. №27197. 
8. Полное собрание законов Российской империи. Второе собрание (1825-1881). Т. ХІ. Ч. 1. №9107; Ч. 2. №9494, №95384; Т. ХХ. Ч. 1. №18590, №19283.

9. Пругавин А.С. Монастырские тюрьмы в борьбе с сектантством: к вопросу о веротерпимости. М.: Посредник, 1906.

10. Ряжев А.С. Неизвестные проекты русского «просвещенного абсолютизма» по делам религии // Отечественная история. 2004. № 2. С. 143-154.

11. Столпянский П.Н. Город Оренбург: материалы к истории и топографии города. Оренбург: Изд-во Оренб. губ. тип., 1908.

12. Субботин Н.И. Моим обвинителям и судьям. М.: тип. Т. Рис, 1877.

13. Три века: Россия от смуты до нашего времени: Ист. сб. под ред. В.В. Каллаша. Т. 1. М.: т-во И.Д. Сытина, 1912-1913.

14. Футорянский Л.И. Казачество России на рубеже веков. Оренбург: ДИМУР, 1997.

15. Чернавский Н.М. Оренбургская епархия в прошлом и настоящем. Вып. 2. Оренбург: Тип. Оренбургской Духовной консистории, $1901-1902$.

16. Ширяев В.Н. Религиозные преступления: Ист.-догмат. очерки. Ярославль: тип. Губ. правл., 1909.

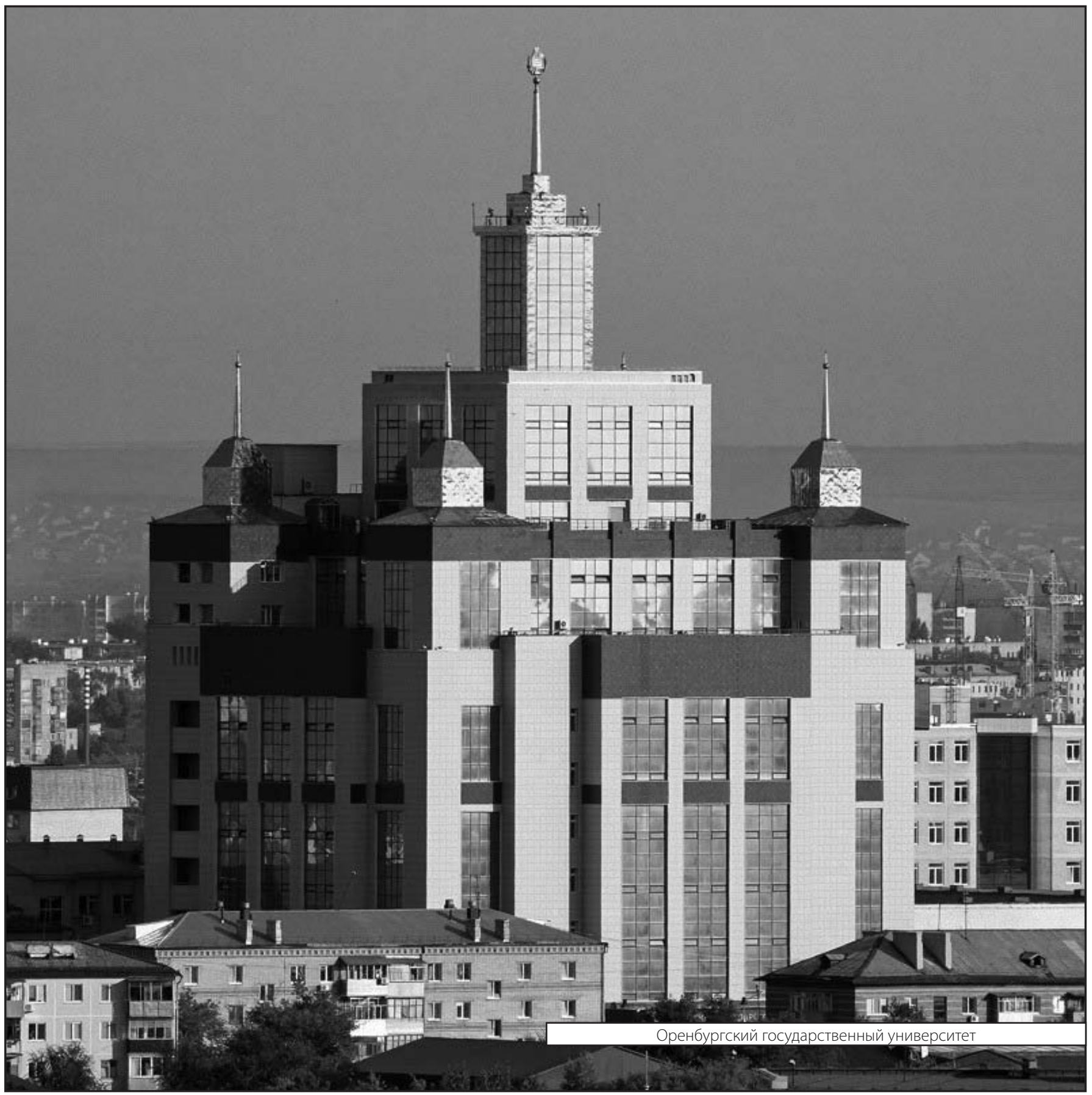

